\section{Who is referred for sedation for dentistry and why?}

\author{
C. A. Boyle, ${ }^{1}$ T. Newton ${ }^{2}$ and P. Milgrom ${ }^{3}$
}

IN BRIEF
Identifies that individuals who are referred
for sedation are highly anxious and fear a
range of different dental stimuli.
- Even patients who are referred for
restorative dentistry can be anxious.
- Anxious patients are likely to attend for
dental care only on an emergency basis.
- Highlights the aspects of dentistry which
cause anxiety.
The drill is more anxiety provoking than
dental injections.

\begin{abstract}
Objective To assess referrals to sedation, examining dental anxiety and background of patients, and compare these characteristics to those referred to a restorative dentistry clinic. Design Descriptive, cross sectional survey. Subjects and methods Subjects were 100 consecutive new patients in sedation and special care and 50 new patients in restorative dentistry at Guy's and St Thomas NHS Foundation Trust. A questionnaire included demographics, self-reported oral health and dental attendance, and dental fear. Information from the patients records was taken: ASA classification, previous sedation or general anaesthesia, alcohol and tobacco use, and medications. Results The best predictors of referral were dental anxiety level and an irregular attendance. The most important fears were seeing, hearing and feeling the vibrations of the dental drill, and the perception of an accelerated heart rate. Other factors such as general, mental and dental health and alcohol use were related to referral but less important. Conclusions Referral is consistent with the goal of the sedation clinic to see anxious patients. Referring general practitioners are able to identify these patients.
\end{abstract}

\section{INTRODUCTION}

A large proportion of adults in the United Kingdom are afraid of dentists. ${ }^{1}$ Approximately one in four adults in the UK delays seeking help for a painful dental condition as a result of their dental fear. Similarly, as many as one in five adults in North America is fearful of the dentist. ${ }^{2}$ The prevalence of dental anxiety has not changed markedly in the last 30 years, in spite of more modern and less painful dental technology.

Fear and anxiety lead to avoidance of dental treatment, which in turn leads to impaired oral health. ${ }^{3}$ Research throughout the world has shown repeatedly that disadvantaged and medically compromised

\footnotetext{
${ }^{1 *}$ Consultant in Special Care Dentistry, ${ }^{3}$ SAAD Visiting Professor of Anxiety and Pain Management, Department of Sedation and Special Care Dentistry, King's College London Dental Institute at Guy's, King's College and St Thomas' Hospitals, Floor 26, Tower Wing, London, SE1 9RT; ${ }^{2}$ Professor of Psychology as Applied to Dentistry, King's College London, Oral Health Services Research \& Dental Public Health, King's College Hospital, Caldecot Road, London, SE5 9RW

Correspondence to: Dr Carole A. Boyle Email: carole.boyle@kcl.ac.uk
}

\section{Online article number E12}

Refereed Paper - accepted 5 December 2008

DOI: 10.1038/sj.bdj.2009.251

${ }^{\oplus}$ British Dental Journal 2009; 206: E12 populations have the greatest levels and frequencies of dental fear. ${ }^{3-9}$

As a result of irregular attendance and delay in seeking treatment, individuals with dental fear tend to be referred for specialist dental care and receive treatment under sedation or general anaesthesia. Data from the Business Services Authority for 2003 (the last year for which data are available) suggests that in primary care alone, over $€ 6$ million was spent on treatment under sedation. This is an underestimate of the total cost because it does not include the costs of secondary care and the community dental service, nor the time lost from productive work and other activities associated with dental infections. Irrespective of the cost, services are often in short supply, making the question of how these services are rationed of public health importance. ${ }^{10}$

\section{OBJECTIVE}

To assess the referrals to a sedation clinic by examining the dental anxiety level and background of patients seeking care being referred, and compare these characteristics to those of patients seeking care at the restorative dentistry clinic.

\section{DESIGN}

This is a descriptive, cross sectional study.

\section{SETTING}

The study was conducted in the departments of sedation and special care dentistry and restorative dentistry at Guy's and St Thomas NHS Foundation Trust. The study was conducted between January and June 2007 in the Division of Restorative Dentistry.

\section{SUBJECTS AND METHODS}

One hundred consecutive patients on a new patient clinic in the department of sedation and special care dentistry and 50 patients attending new patient clinics in restorative dentistry at Guy's and St Thomas NHS Foundation Trust. Patients being evaluated for the sedation clinic (SC) have been referred because their general dental practitioner has been unable to provide dental care due to their anxiety. Patients attending the restorative clinic (RC) have been referred for complex dental problems.

Patients were approached by a member of the staff while waiting to be seen by the dentist. At the SC they were told 
'We hope that by finding out why people are anxious about coming to the dentist we will be able to improve our service.' At the restorative clinic patients were given the same information but additionally told 'You might not be very anxious yourself but we plan to compare results with people attending our anxiety clinics.' The number of people refusing to take part in each setting was documented.

The study was reviewed and approved by the Research Ethics Committee of St Thomas' Hospital. The survey was confidential and the informed consent of each participant was obtained.

A 34-item written questionnaire was administered after confirmation that the patients was able to read and write English and were happy to answer questions. The questionnaire included demographic information, self-reported oral health (four-point Likert-like scale ranging from poor to excellent), self-reported dental attendance (five-point Likert-like scale ranging from 'only when I need to' to 'more often than every six months') and reasons for visits to the dentist (emergency treatment or routine checkup, cleaning or filling), anxiety regarding dental injections (five items ranging from not at all true to absolutely true), ${ }^{11}$ and a general measure of dental fear (Dental Fear Survey (DFS), 20 items, five-point scales) as well as the subscores on the DFS for anticipation, specific fears and physiology. ${ }^{12}$ Additional items were included in the questionnaire to capture other aspects of dental anxiety. The questionnaire was pre-tested before use. Information was taken from the patients' medical records: American Society of Anesthesiologists classification (ASA), previous sedation or general anaesthesia for dentistry and alcohol and tobacco use, and a note made of medication taken by the patients.

The data were entered into Excel, edited, and analysed using SPSS (Statistical Package for the Social Sciences, version 13).

\section{Main outcome measures}

The main outcome variable was treatment at the sedation and special care dentistry clinic (SC) or the restorative dentistry clinic. In regression
Table 1 Summary of the demographic characteristics of participants from the sedation and restorative clinics

\begin{tabular}{|l|l|l|}
\hline & $\begin{array}{l}\text { Participants from } \\
\text { restorative clinic } \\
(n=50)\end{array}$ & $\begin{array}{l}\text { Participants from } \\
\text { sedation clinic } \\
(n=100)\end{array}$ \\
\hline Highest education level & \multicolumn{2}{|l}{} \\
\hline O Levels & 8 & 57 \\
\hline A Levels & 7 & 10 \\
\hline BTEC & 3 & 12 \\
\hline Degree & 8 & 8 \\
\hline Postgraduate qualifications & 9 & 3 \\
\hline Missing data & $(15)$ & $(10)$ \\
\hline
\end{tabular}

Chi square $=26.9 ; p<0.001$

\section{Self-reported oral health}

\begin{tabular}{l|l|l}
\hline Poor & 6 & 52 \\
\hline Fair & 20 & 26 \\
\hline Good & 18 & 20 \\
\hline Excellent & 6 & 1 \\
\hline
\end{tabular}

Chi square $=27.8 ; p<0.001$

\begin{tabular}{|l|l|l|}
\hline Reason for attendance & 16 & 55 \\
\hline Routine & 24 & 25 \\
\hline Emergency treatment & 10 & 19 \\
\hline Other & & $(1)$ \\
\hline Missing data & & Chisquae $=91$ p $<0.05$
\end{tabular}

Chi square $=9.1 ; p<0.05$

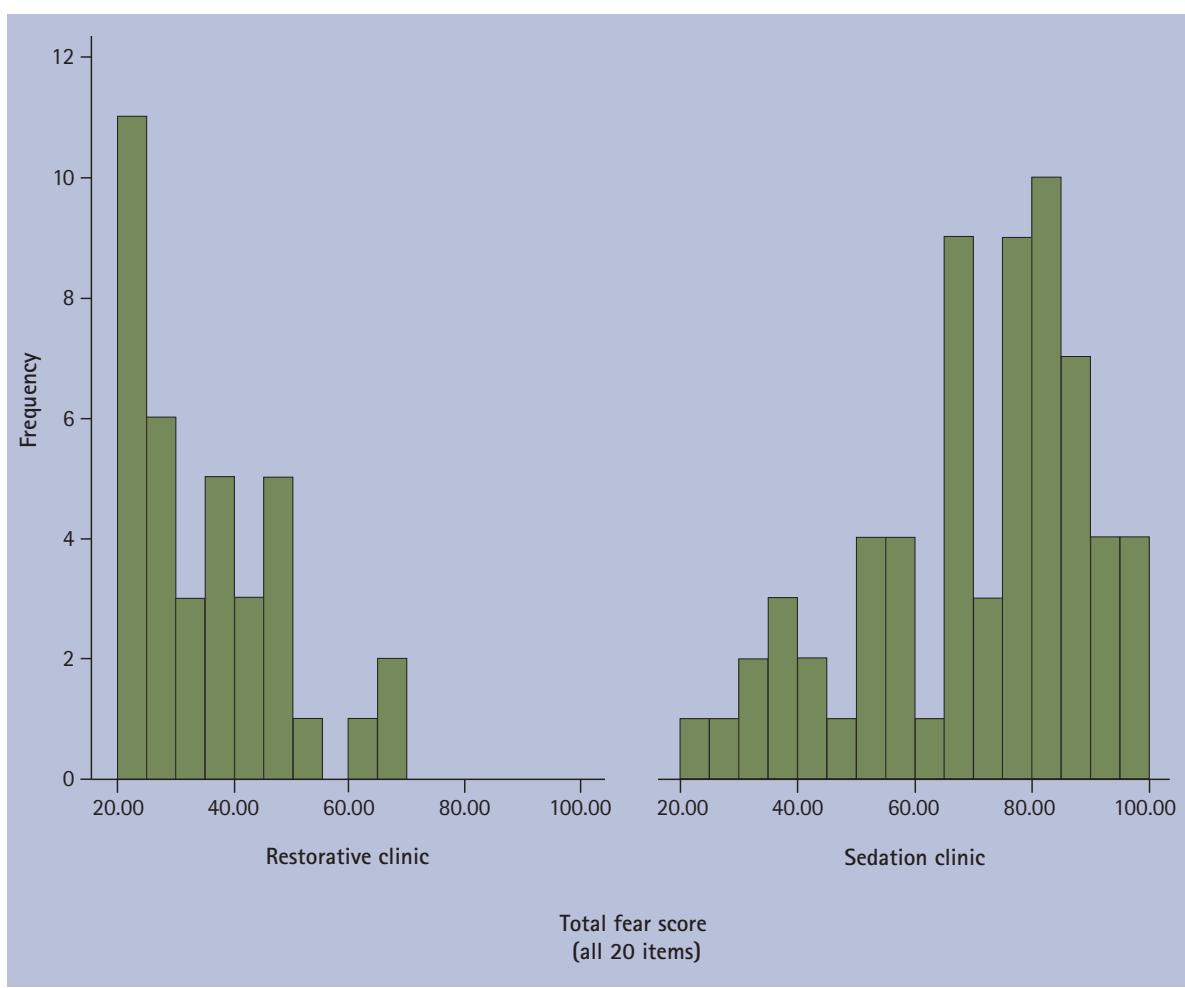

Fig. 1 Dental Fear Survey score by clinic 
Table 2 Frequencies of responses to individual items on the Dental Fear Survey by participants attending the sedation clinic $(n=100)$ and the restorative clinic $(n=50)$

\begin{tabular}{|c|c|c|c|c|c|c|c|c|c|c|c|}
\hline \multirow{2}{*}{$\begin{array}{l}\text { Item } \\
\text { How much anxiety do } \\
\text { each of the following } \\
\text { cause you? }\end{array}$} & \multicolumn{5}{|c|}{ Participants attending restorative clinic $(n=50)$} & \multicolumn{5}{|c|}{ Participants attending sedation clinic $(n=100)$} & \\
\hline & $\begin{array}{l}\text { Not } \\
\text { at all }\end{array}$ & A little & $\begin{array}{l}\text { Some- } \\
\text { what }\end{array}$ & Much & $\begin{array}{l}\text { Very } \\
\text { much }\end{array}$ & $\begin{array}{l}\text { Not } \\
\text { at all }\end{array}$ & A little & $\begin{array}{l}\text { Some- } \\
\text { what }\end{array}$ & Much & $\begin{array}{l}\text { Very } \\
\text { much }\end{array}$ & \\
\hline $\begin{array}{l}\text { Making an appointment } \\
\text { for dentistry }\end{array}$ & 39 & 4 & 4 & 0 & 1 & 26 & 29 & 19 & 5 & 17 & $\begin{array}{l}\mathrm{Chi}^{2}=38.9, \\
\mathrm{p}<0.001\end{array}$ \\
\hline $\begin{array}{l}\text { Approaching the } \\
\text { dentist's surgery }\end{array}$ & 32 & 6 & 7 & 3 & 0 & 16 & 23 & 18 & 20 & 22 & $\begin{array}{l}\mathrm{Chi}^{2}=42.1 \\
\mathrm{p}<0.001\end{array}$ \\
\hline Sitting in the waiting room & 24 & 17 & 4 & 2 & 1 & 17 & 16 & 21 & 23 & 22 & $\begin{array}{l}\mathrm{Chi}^{2}=36.3 \\
\mathrm{p}<0.001\end{array}$ \\
\hline $\begin{array}{l}\text { Being seated in the } \\
\text { dental chair }\end{array}$ & 18 & 20 & 5 & 5 & 1 & 8 & 10 & 21 & 20 & 39 & $\begin{array}{l}\mathrm{Chi}^{2}=51.5 \\
\mathrm{p}<0.001\end{array}$ \\
\hline $\begin{array}{l}\text { The smell of the } \\
\text { dentist's surgery }\end{array}$ & 30 & 14 & 3 & 1 & 0 & 22 & 12 & 19 & 18 & 28 & $\begin{array}{l}\mathrm{Chi}^{2}=43.8, \\
\mathrm{p}<0.001\end{array}$ \\
\hline Seeing the dentist walk in & 34 & 11 & 2 & 1 & 0 & 25 & 15 & 20 & 10 & 29 & $\begin{array}{l}\mathrm{Chi}^{2}=40.2 \\
\mathrm{p}<0.001\end{array}$ \\
\hline $\begin{array}{l}\text { Seeing the } \\
\text { anaesthetic needle }\end{array}$ & 18 & 12 & 8 & 5 & 5 & 15 & 11 & 13 & 17 & 42 & $\begin{array}{l}\mathrm{Chi}^{2}=22.7 \\
\mathrm{p}<0.001\end{array}$ \\
\hline Feeling the needle injected & 15 & 14 & 7 & 6 & 5 & 13 & 19 & 7 & 13 & 44 & $\begin{array}{l}\mathrm{Chi}^{2}=20.1 \\
\mathrm{p}<0.001\end{array}$ \\
\hline Seeing the drill & 15 & 11 & 9 & 8 & 5 & 7 & 8 & 7 & 18 & 58 & $\begin{array}{l}\mathrm{Chi}^{2}=39.6, \\
p<0.001\end{array}$ \\
\hline Hearing the drill & 16 & 10 & 9 & 6 & 6 & 6 & 12 & 5 & 12 & 63 & $\begin{array}{l}\mathrm{Chi}^{2}=44.2 \\
\mathrm{p}<0.001\end{array}$ \\
\hline $\begin{array}{l}\text { Feeling the vibrations } \\
\text { of the drill }\end{array}$ & 15 & 9 & 10 & 6 & 8 & 4 & 10 & 6 & 12 & 64 & $\begin{array}{l}\mathrm{Chi}^{2}=41.6, \\
p<0.001\end{array}$ \\
\hline Having your teeth cleaned & 25 & 10 & 8 & 4 & 0 & 13 & 14 & 16 & 20 & 27 & $\begin{array}{l}\mathrm{Chi}^{2}=35.4, \\
\mathrm{p}<0.001\end{array}$ \\
\hline $\begin{array}{l}\text { Having } X \text {-rays put } \\
\text { in my mouth }\end{array}$ & 34 & 7 & 5 & 1 & 1 & 40 & 17 & 15 & 13 & 12 & $\begin{array}{l}\mathrm{Chi}^{2}=14.3, \\
\mathrm{p}<0.001\end{array}$ \\
\hline $\begin{array}{l}\text { Having models or } \\
\text { impressions of my mouth }\end{array}$ & 23 & 12 & 4 & 4 & 4 & 33 & 18 & 15 & 9 & 16 & $\begin{array}{l}\mathrm{Chi}^{2}=5.0, \\
\mathrm{~ns}\end{array}$ \\
\hline \multirow[t]{2}{*}{$\begin{array}{l}\text { All things considered, how } \\
\text { scared are you of having } \\
\text { dentistry done? }\end{array}$} & 19 & 16 & 12 & 2 & 0 & 6 & 8 & 5 & 15 & 66 & $\begin{array}{l}\mathrm{Chi}^{2}=80.2 \\
\mathrm{p}<0.001\end{array}$ \\
\hline & Never & $\begin{array}{l}\text { Once or } \\
\text { twice }\end{array}$ & $\begin{array}{l}\text { A few } \\
\text { times }\end{array}$ & Often & $\begin{array}{l}\text { Nearly } \\
\text { every } \\
\text { time }\end{array}$ & Never & $\begin{array}{l}\text { Once or } \\
\text { twice }\end{array}$ & $\begin{array}{l}\text { A few } \\
\text { times }\end{array}$ & Often & $\begin{array}{l}\text { Nearly } \\
\text { every } \\
\text { time }\end{array}$ & \\
\hline $\begin{array}{l}\text { Has fear of dentistry ever } \\
\text { caused you to put off } \\
\text { making an appointment? }\end{array}$ & 44 & 5 & 0 & 0 & 0 & 41 & 42 & 0 & 15 & 0 & $\begin{array}{l}\mathrm{Chi}^{2}=31.4 \\
\mathrm{p}<0.001\end{array}$ \\
\hline $\begin{array}{l}\text { Has fear of dentistry ever } \\
\text { caused you to cancel or not } \\
\text { turn up for an appointment? }\end{array}$ & 13 & 18 & 9 & 4 & 2 & 6 & 16 & 18 & 14 & 35 & $\begin{array}{l}\mathrm{Chi}^{2}=30.0, \\
p<0.001\end{array}$ \\
\hline
\end{tabular}

analysis, this variable either took the value of 1 when the patient was seen at the SC or 0 when treated in the restorative dentistry clinic.

\section{RESULTS}

One hundred consecutive new patients from the SC (77\% female, mean age 36.5 years, range 16-67) and 50 consecutive new patients from the restorative clinic (52\% female, mean age 42.4 years, range 15-75) participated in the study. There were three people who declined to take part in the sedation group and none in the restorative group. The level of education reached by the participants in the two groups is summarised in Table 1. Of the sedation group, 81\% were white, as were $70 \%$ of the restorative group (35/50).

The typical patient reported 'poor' dental health (SC mode poor 52\%; RC mode fair $40 \%$ ). There was a difference in self-reported dental health between the clinics. (Table 1).

There was a difference in self-reported attendance between the clinics (SC mode 'only when I need to' 51\%; RC mode 'about every six months' 66\%; chi square 47.5). There was also a significant difference in the reasons for attending: $55 \%$ of the sedation patients attended only for emergency treatment while 48\% of restorative patients attended for routine care (Table 1).

The majority of the patients in both clinics had never had sedation or a general anaesthetic for dental care before (SC 72\% had not had previous sedation or GA; RC 92\% had not had previous sedation or GA). Fifty-nine of 150 patients were either ASA II (55/150) or ASA III (4/150). There was no difference in the ASA between clinics, although all four ASA III patients were in the SC. 
Table 3 Frequencies of responses to individual items on the Fear of Injections scale by participants attending the sedation clinic $(n=100)$ and the restorative clinic $(n=50)$

\begin{tabular}{|c|c|c|c|c|c|c|c|c|c|c|c|}
\hline \multirow{2}{*}{$\begin{array}{l}\text { Item } \\
\text { Concerning dental injec- } \\
\text { tions I believe that... }\end{array}$} & \multicolumn{5}{|c|}{ Participants attending restorative clinic $(n=50)$} & \multicolumn{5}{|c|}{ Participants attending sedation clinic $(n=100)$} & \\
\hline & $\begin{array}{l}\text { Not at } \\
\text { all true }\end{array}$ & $\begin{array}{l}\text { A little } \\
\text { true }\end{array}$ & $\begin{array}{l}\text { Some- } \\
\text { what true }\end{array}$ & $\begin{array}{l}\text { Very } \\
\text { true }\end{array}$ & $\begin{array}{l}\text { Absolutely } \\
\text { true }\end{array}$ & $\begin{array}{l}\text { Not at } \\
\text { all true }\end{array}$ & $\begin{array}{l}\text { A little } \\
\text { true }\end{array}$ & $\begin{array}{l}\text { Some- } \\
\text { what true }\end{array}$ & $\begin{array}{l}\text { Very } \\
\text { true }\end{array}$ & $\begin{array}{l}\text { Absolutely } \\
\text { true }\end{array}$ & \\
\hline $\begin{array}{l}\text { Nothing is as painful as } \\
\text { a needle in my mouth }\end{array}$ & 22 & 11 & 12 & 1 & 2 & 17 & 11 & 24 & 13 & 32 & $\begin{array}{l}\mathrm{Chi}^{2}=28.0 \\
\mathrm{p}<0.001\end{array}$ \\
\hline $\begin{array}{l}\text { Seeing the needle } \\
\text { is terrifying }\end{array}$ & 19 & 17 & 11 & 2 & 0 & 15 & 16 & 14 & 16 & 39 & $\begin{array}{l}\mathrm{Chi}^{2}=37.7 \\
\mathrm{p}<0.001\end{array}$ \\
\hline $\begin{array}{l}\text { Seeing the needle come } \\
\text { closer to my mouth is scary }\end{array}$ & 17 & 18 & 7 & 5 & 2 & 15 & 11 & 14 & 14 & 41 & $\begin{array}{l}\mathrm{Chi}^{2}=32.4 \\
\mathrm{p}<0.001\end{array}$ \\
\hline $\begin{array}{l}\text { I don't know why needles } \\
\text { are so terrifying to me. } \\
\text { They just are! }\end{array}$ & 26 & 13 & 7 & 2 & 0 & 20 & 15 & 13 & 10 & 38 & $\begin{array}{l}\mathrm{Chi}^{2}=33.8 \\
\mathrm{p}<0.001\end{array}$ \\
\hline $\begin{array}{l}\text { Just the idea of the needle } \\
\text { penetrating my body is } \\
\text { terrifying }\end{array}$ & 24 & 14 & 6 & 3 & 2 & 26 & 14 & 16 & 9 & 35 & $\begin{array}{l}\mathrm{Chi}^{2}=22.2, \\
\mathrm{p}<0.001\end{array}$ \\
\hline
\end{tabular}

Overall $47 \%$ of patients in the SC (mean 15.7 years, range 1-30) and 26\% of patients in the restorative clinic (mean 14.0 years, range 1-40) used tobacco. The typical patient self-reported consuming three units of alcohol (SC 3.7 units mean, range 0-35; RC 2.1 units mean, range 0-14). Sixty-five percent of patients reported not using any alcohol. Fifty-seven percent of those in the SC reported using alcohol versus only 16 percent of those in the RC (Fisher's exact test, $\mathrm{p}<0.0001$ ).

The total Dental Fear Survey scores (DFS) for the two clinics were 69.8 (18.9 SD, range 20-97) for the SC and 35.1 (13.6 SD, range 20-68) for the RC. There was a difference in DFS score $(t=9.8)$. The distribution of the scores for the two clinics is shown in Figure 1.

The two clinics also differed in the same manner on each of the three subscores ( $\mathrm{t}=11.2,8.5$, and 9.9 respectively): anticipation SC mean (SD) = 9.8 (3.0), RC mean $(\mathrm{SD})=4.6(1.8)$; specific fears $\mathrm{SC}$ mean $(\mathrm{SD})=42.0$ (12.7), RC mean (SD) $=23.4$ (9.4); physiology SC mean (SD) = 17.7 (5.3), RC mean (SD) =8.4 (3.8).

Table 2 gives the individual items in the DFS. The two clinics differed in the importance of various fears. Among the top five fears, the three items addressing the dental drill, overall fear and the physiological response to fear of a high heart rate were most important in the SC. In the RC, the three drill items also appeared in the top five but the overall fear and physiological response questions were rated lower. The only item where there was no significant difference between the two clinics was in taking impressions.

The five items of the dental injection fear instrument were added to give a score from 5 to 25 , where 25 indicates a maximal fear of dental injections. The mean score was 16.6 (7.0 SD, range 5-25) for the SC and 9.6 (SD 4.3, range 5-19) for the RC. There were differences between the populations $(t=6.3)$. The individual item responses are given in Table 3.

The responses to the two questionnaires are highly correlated $(R=0.53, p$ $<0.001$ for the $\mathrm{SC}$ and $\mathrm{R}=0.67, \mathrm{p}<0.001$ for the $\mathrm{RC}$ ).

\section{Cross sectional analyses}

Scores on the DFS were dichotomised using the previously established cut-off of 37. When the fearful patients in each clinic were compared, the SC population was more likely to be male (44vs $19 \%$, chi square $=6.6$, df $1, \mathrm{p}=0.01$ ) and be more poorly educated (0 levels 65 vs 24\%, chi square $=24.0$, df 4 , $\mathrm{p}<0.0001$ ).

A logistic regression analysis was conducted where the type of clinic referral (SC vs R) was examined relative to patient characteristics (sex, age, education, regular attendance, tobacco and alcohol use, mental health and use of medications). The results show that patients who are fearful and have had a pattern of irregular attendance are 5.9 and 4.9 times respectively more likely have been referred to the SC ( $p<0.05)$. Other characteristics of the patients were not independently related to the referral site in this multivariable analysis.

\section{CONCLUSIONS}

A previous study of referrals to secondary care for anxious patients found that most were for sedation. ${ }^{13}$ The investigators found that three out of ten of these patients opted for psychological treatment for their fears. Nevertheless, very few psychological services are available for dentally anxious individuals in the UK or elsewhere. As a result, many avoid dentistry altogether, while others only agree to referral for dental treatment under sedation or general anaesthesia, which is in short supply and expensive. Increasing the availability of conjoint treatment with psychological interventions of proven efficacy addressing fears and sedation used to facilitate urgent care will increase access to dental services with consequential improvements in oral health and general well being. The impact of oral ill health on general health and quality of life is established and is particularly marked in individuals with dental anxiety. ${ }^{14}$

Addressing the two objectives of the study, we determined that $62 \%$ of the sedation clinic patients had high dental fear (score over 37) compared with 18\% in the restorative clinic. There were significantly more high anxiety patients in the sedation clinic than in the restorative clinic, making the sedation clinic an appropriate venue for research and clinical trials on the treatment of fearful dental patients. Participation in the study was high, suggesting the patients are typical of those being referred by their general dental practitioner because they are too anxious to receive treatment in a normal setting. 
This research was supported, in part, by a grant from the Society for the Advancement of Anaesthesia in Dentistry (SAAD). We acknowledge the advice of Dr David Craig of the King's College Dental Institute and Emeritus Professor Isaac Marks of the Institute of Psychiatry in carrying out this study and the assistance of the dental nurses in both sedation and restorative clinics. Thanks also to Brian Smith, retired consultant in restorative dentistry.

1. Nuttall N M, Bradnock G, White D, Morris J, Nunn $J$. Dental attendance in 1998 and implications for the future. Br Dent J 2001; 190: 177-182.

2. Smith $T A$, Heaton $L J$. Fear of dental care: are we making any progress? J Am Dent Assoc 2003; 134: 1101-1108.

3. McGrath C, Bedi R. The association between dental anxiety and oral health-related quality of life in
Britain. Community Dent Oral Epidemiol 2004; 32: 67-72.

4. Berggren U. General and specific fears in referred and self-referred adult patients with extreme dental anxiety. Behav Res Ther 1992; 30: 395-401.

5. Hardie R, Ransford E, Zernik J. Dental patients' perceptions in a multiethnic environment. J Calif Dent Assoc 1995; 23: 77-80.

6. Holtzman J M, Berg R G, Mann J, Berkey D B. The relationship of age and gender to fear and anxiety in response to dental care. Spec Care Dentist 1997; 17: 82-87.

7. Milgrom P, Mancl L, King B, Weinstein P. Origins of childhood dental fear. Behav Res Ther 1995: 33: 313-319.

8. Tomar S L, Azevedo A B, Lawson R. Adult dental visits in California: successes and challenges. J Public Health Dent 1998; 58: 275-280.

9. Ragnarsson E. Dental fear and anxiety in an adult
Icelandic population. Acta Odonto/ Scand 1998; 56: 100-104.

10. Allen E M, Girdler N M. Attitudes to conscious sedation in patients attending an emergency dental clinic. Primary Dent Care 2005; 12: 27-32.

11. Milgrom P, Coldwell S E, Getz T, Ramsay D $S_{1}$ Weinstein P. Four dimensions of fear of dental injections. J Am Dent Assoc 1997; 128: 756-766.

12. Kleinknecht R A, Thorndike R M, McGlynn F D, Harkavy J. Factor analysis of the dental fear survey with cross-validation. J Am Dent Assoc 1984; 108: 59-61.

13. McGoldrick P, Levitt J, deJongh A, Mason A, Evans D. Referrals to a secondary care dental clinic for anxious adult patients: implications for treatment. Br Dent J 2001; 191: 686-688.

14. Cohen S M. Fiske J, Newton J T. The impact of dental anxiety on daily living. Br Dent J 2000; 189: 385-390. 